\title{
Association Between MGMT Promoter Methylation and Breast Cancer: a Meta-Analysis
}

\author{
Nairui An Yu Shi Peng Ye Zhongya Pan Xinghua Long \\ Department of Laboratory Medicine, Zhongnan Hospital of Wuhan University, Wuhan, China
}

\section{Key Words}

Mgmt • Breast Cancer • Methylation $•$ Metastasis $•$ Diagnosis

\begin{abstract}
Background/Aims: Numerous studies have suggested that the promoter methylation status of 06-methylguanine-DNA methyltransferase (MGMT) is significantly associated with breast cancer. However, these studies have not demonstrated consistent results. Methods: To obtain more accurate results for this possible association, we performed a meta-analysis-based study using the relevant data. A total of 14 articles were included in this meta-analysis. Results: Our study showed that the frequency of MGMT promoter methylation was significantly higher in patients with breast cancer than non-breast cancer subjects with an Odds Ratio (OR) of 4.47, a 95\% Confidence Interval (CI) ranging between 1.95 - 10.25 and a P value of 0.0004 . Moreover, MGMT methylation was significantly associated with the negative expression of the MGMT protein $(\mathrm{OR}=4.65,95 \% \mathrm{CI}=2.66-8.12, \mathrm{P}<0.00001)$, Oestrogen Receptor (ER)-negative tumours $(\mathrm{OR}=1.79,95 \% \mathrm{CI}=1.09-2.93, \mathrm{P}=0.02)$, postmenopausal status $(\mathrm{OR}=1.84,95 \% \mathrm{CI}$ $=1.18-2.87, \mathrm{P}=0.007)$ and histological grade III tumours $(\mathrm{OR}=2.49,95 \% \mathrm{CI}=1.53-4.07$, $\mathrm{P}=0.0003$ ) in breast cancer patients. However, breast cancer was not significantly correlated with lymph node metastasis $(\mathrm{OR}=1.19,95 \% \mathrm{CI}=0.83-1.70, \mathrm{P}=0.35)$, Progesterone Receptor $(\mathrm{PR})$ status $(\mathrm{OR}=1.08,95 \% \mathrm{CI}=0.58-2.00, \mathrm{P}=0.81)$, Human epidermal growth factor receptor - $2(\mathrm{HER}-2 / \mathrm{neu})$ status $(\mathrm{OR}=1.01,95 \% \mathrm{CI}=0.65-1.57, \mathrm{P}=0.97), \mathrm{P} 53$ mutation $(\mathrm{OR}=1.30,95 \% \mathrm{CI}=0.76-2.21, \mathrm{P}=0.34)$ and age $>50(\mathrm{OR}=1.07,95 \% \mathrm{CI}=0.46-2.51, \mathrm{P}=$ 0.88). Conclusions: Our study suggests that MGMT promoter methylation may be an early biomarker for the diagnosis of breast cancer.
\end{abstract}

(C) 2017 The Author(s)

Published by S. Karger AG, Basel

\section{Introduction}

Cancer is a type of malignant tumour that originates in the epithelial tissue. Cancer may be the synthetic result of acquired inheritance in somatic cells, the genome and epigenetic alterations in cancer cells [1]. Breast cancer is the most common type of cancer in women 


\section{Cellular Physiology Cell Physiol Biochem 2017;42:2430-2440

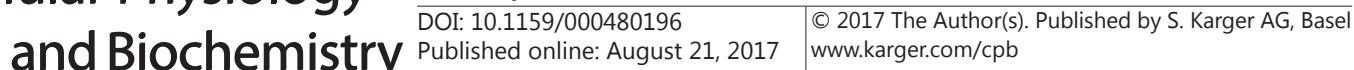 \\ An et al.: MGMT Promoter Methylation in Breast Cancer}

and the primary cause of death among women worldwide [2-6]. The pathogenesis of breast cancer is still not clear; however, advances in molecular biology have led more researchers to study the epigenetics of breast cancer. Esteller et al. provided evidence to strongly support epigenetic mechanisms, including the methylation of cytosines in DNA, changes in histone and chromatin structure due to the covalent posttranslational modifications of histone proteins and alterations in the expression of microRNAs in the progression of breast tumourigenesis $[7,8]$. The alterations in epigenetics, particularly in the methylation status of the CpG islands of DNA promoter regions, were considered as early events in cancer [9], which play crucial roles in tumour progression and may serve as biomarkers for cancer diagnosis [10-12]. DNA methylation in mammals occurs at carbon-5 of the cytosine residues of cytosine-phosphatidyl-guanosine (CpG) dinucleotides [12]. DNA methylation fulfils the essential requirements of epigenetic cyphers by stably regulating gene expression and maintaining the mechanism of these expression patterns through mitosis [13]. Mitosis can sufficiently account for the gene expression of these specific patterns from imprinting $\mathrm{X}$-inactivation to germ cell-restricted gene expression observed in mature organisms [14]. Notably, increasing evidence suggests that the regulation of DNA methylation patterns involves microRNAs. Sun et al. found that miR-361-5p was significantly down regulated in hepatocellular carcinoma tissues due to epigenetic mechanisms involving DNA methylation [15]. A study by Teng et al. has shown that the transcriptional silencing of miR-29b in epithelial ovarian cancer cells is associated with the hypermethylation of CpG islands [16]. MGMT, located on chromosome 10q26, is a DNA repair gene that encodes the DNA-repair protein $0^{6}$-alkylguanine $\left(\mathrm{O}^{6}\right.$-AG) DNA alkyl transferase (AGT) [17], which transfers the alkyl group from the 06 position of guanine in DNA to a cysteine residue of its active site [4,17-21]. If the alkyl group is not removed, the interchain cross-links formed by 06-alkyl guanine would inhibit DNA replication and cause the incorporation of incorrect base pairs [4]. Moreover, 06-methylguanine has the tendency to pair with thymine during replication [22] and trigger the conversion of G-to-A during base-pairing, causing mutations together with other factors. The MGMT protein restores guanine and inactivates itself during the process [4], providing to the cell a significant defence mechanism against tumourigenesis [23]. MGMT methylation has been reported to occur in one-third of all breast cancers, irrespective of the hormone receptors and Her-2 status [24]. Currently, the study of MGMT methylation is no longer confined to tumour tissues. Spitzwieser et al. tested the applicability of the MGMT promoter methylation as biomarkers in breast cancer tissues, tumour-adjacent and tumour-distant tissues [12], Taback et al. used bone marrow (BM) aspirates and paired serum samples [25] and Sharma et al. used the serum of breast cancer patients [22] to detect MGMT methylation. These studies concluded that the percentages of MGMT promoter methylation were different among tumour tissues, paired adjacent normal tissues and peripheral blood derived from the breasts cancers of healthy women. Recently, many researchers have studied the association between MGMT promoter methylation and breast cancer risk or its clinicopathological features. Perhaps, small samples or errors existed among different studies due to which the percentage of MGMT methylation as well as its association with clinicopathological features or breast cancer risk were not always consistent. To obtain more reliable and systematic results, we performed a meta-analysis to implicate MGMT gene promoter methylation as a risk factor for breast cancer and study its association with clinicopathological features.

\section{Materials and Methods}

\section{Search Strategy}

Two independent retrievers (Nairui An and Yu Shi) searched and obtained information from previously published studies. All articles contained in this meta-analysis are from PubMed, CNKI and EMBASE databases and date up to April 2017. The keywords used to carry out this search were: 'MGMT' or 'O6-methylguanineDNA methyltransferase', 'DNA methylation' or 'methylation' or 'promoter methylation' and 'breast cancer' or 'breast tumour' or 'breast carcinoma'. 
Inclusion criteria. (1) Studies related to MGMT gene promoter methylation and breast cancer risk or clinicopathological features. (2) Data used to calculate OR and 95\% CI that could be obtained directly or indirectly. (3) The study included human female participants.

Exclusion Criteria. (1) The reviewed literature included review articles, case reports, abstracts and letters. (2) Cell lines. (3) Repetitive articles: notably, only the most recent and most complete articles were included. (4) Although there were complete cases of MGMT promoter methylation, the number of unmethylated controls were vague or absent.

\section{Literature Screening and Data Extraction}

The literature was strictly selected according to the inclusion and exclusion criteria. Nairui An, Peng Ye and Zhongya Pan extracted data independently from qualified articles, and any inconsistencies were resolved by consensus. A standard protocol was applied to extract data, which were retrieved from qualified studies including the surname of the first author, the year of publication, country, specimen type, methylation quantitative detection methods, the number of MGMT gene promoter methylation and unmethylation in the case group and the control group, as well as controls and cases characteristics.

\section{Statistical Analysis}

RevMan5.3 Software from Cochrane Collaboration and STATA 13.1 were used for statistical analysis. OR and its corresponding 95\%CI were used for quantifying the association between MGMT gene promoter methylation and breast cancer risk or clinicopathological characteristics. The heterogeneity among the included studies was verified by the $\chi 2$ test based on $Q$ - test. $P$ value $\geq 0.10$ and $I^{2} \leq 50 \%$ indicated that the literature was homogeneous. The fixed effect model (Mantel-Haenszel) [26] was used for this meta-analysis. Similarly, $\mathrm{P}<0.10$ or $\mathrm{I}^{2}>50 \%$ indicated the existence of heterogeneity among literature, and the Random effect model (DerSimonian Laird) [27] was used. The $\mathrm{I}^{2}$ value from the $\chi 2$ test was used to represent the degree of heterogeneity. It is believed that there is no heterogeneity if $\mathrm{I}^{2}$ is in the range from $0 \%$ to $25 \%$ while the range from $25 \%$ to $50 \%$ shows moderate heterogeneity. Moreover, the range from $50 \%$ to $75 \%$ indicates large heterogeneity and the range from $75 \%$ to $100 \%$ implies extremely large heterogeneity [28]. A sensitivity analysis was performed to observe the stability of the results by deleting one study at each time in our meta-analysis. We used funnel plots and Egger's linear regression to evaluate the publication bias of the included literature. If the funnel plot is visually symmetric and the P value from the Egger's test is greater than 0.05 , there is no statistically apparent publication bias. All statistical tests were bilateral in our meta-analysis. The consolidated ORs were based on the Z-test, and a P value of less than 0.05 was considered to be statistically significant unless otherwise stated.

\section{Results}

\section{Qualified Study Characteristics}

According to the retrieval scheme of this study, we initially obtained 178 articles. Ultimately, 14 articles [4, 12, 22-25, 29-35] and Fu [2009] (unpublished data) met the inclusion and exclusion criteria of our meta-analysis. The flow chart of the specific screening process is shown in Fig. 1. Notably, one study [22] examined the methylation of MGMT promoter in breast cancer and normal tissues and paired serum and serum from healthy female participants. Because of different study materials, we considered them as two separate case-control studies. Therefore, 15 studies overall were involved in our meta-analysis. Ten studies [12, 22, 25, 29-32, 34, 35] and $\mathrm{Fu}$ [2009] (unpublished data) involving

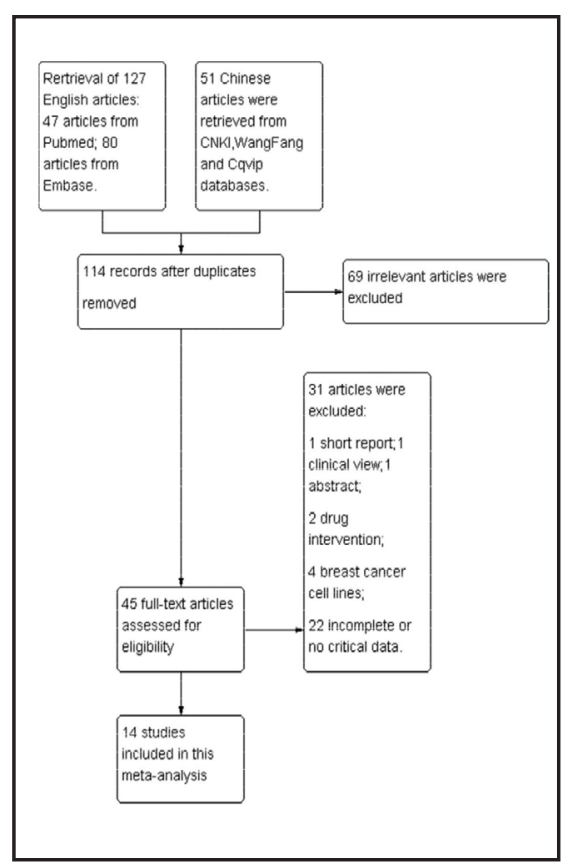

Fig. 1. Flow diagram of the study selection process in this meta-analysis. 


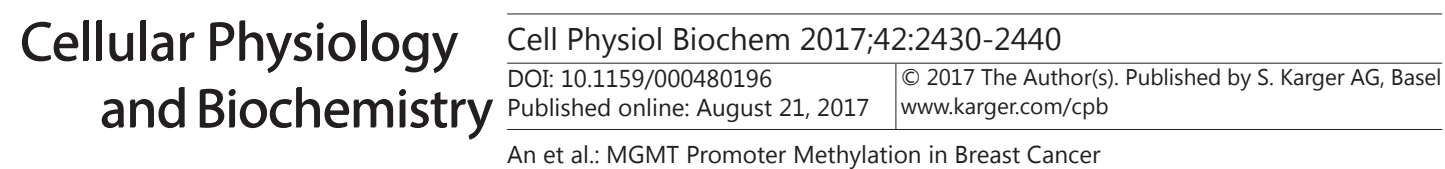

Table 1. Characteristics of studies included in the association of MGMT methylation and breast cancer risk in this meta-analysis. M: methylated; UM: unmethylated; MS-HRM: methylation-sensitive high-resolution melting; MSP: Methylation-specific PCR; qMSP: Quantitative methylation-specific PCR; BM: bone marrow

\begin{tabular}{|c|c|c|c|c|c|c|c|}
\hline First author & Year & Country & Materials & Methods & $\begin{array}{c}\text { Case } \\
\text { M/UM } \\
\end{array}$ & $\begin{array}{c}\text { Control } \\
\mathrm{M} / \mathrm{UM} \\
\end{array}$ & $\begin{array}{c}\text { Control } \\
\text { characteristics }\end{array}$ \\
\hline Zemlyakova[32] & 2003 & Russia & Tissue & Multiplex MSP & $8 / 97$ & $0 / 35$ & $\begin{array}{l}\text { Five normal breast } \\
\text { tissues and } \\
\text { peripheral blood } \\
\text { lymphocytes of } 30 \\
\text { healthy subjects }\end{array}$ \\
\hline TABACK [25] & 2006 & USA & Serum & qMSP & $2 / 31$ & $0 / 10$ & $\begin{array}{l}\text { Peripheral blood } \\
\text { from healthy } \\
\text { females }\end{array}$ \\
\hline $\begin{array}{l}\text { Fu [unpublished } \\
\text { data] }\end{array}$ & 2009 & China & Plasma & $\begin{array}{c}\text { Multiplex } \\
\text { nested- MSP }\end{array}$ & $11 / 47$ & $3 / 35$ & $\begin{array}{l}\text { Plasma of Benign } \\
\text { breast diseases }\end{array}$ \\
\hline Sharma [22] & 2010 & India & Serum & MSP & $26 / 74$ & $0 / 30$ & $\begin{array}{c}\text { Sera from healthy } \\
\text { females }\end{array}$ \\
\hline Alkam [31] & 2013 & Japan & Tissue & MSP & $7 / 19$ & $0 / 3$ & $\begin{array}{l}\text { Normal breast } \\
\text { tissues }\end{array}$ \\
\hline Klajic [30] & 2013 & Norway & Tissue & pyrosequencing & $24 / 170$ & $0 / 6$ & $\begin{array}{l}\text { Normal breast } \\
\text { biopsies }\end{array}$ \\
\hline $\mathrm{Fu}[35]$ & 2014 & China & Tissue & MSP & $20 / 86$ & $5 / 101$ & $\begin{array}{l}\text { Paired normal } \\
\text { breast tissues }\end{array}$ \\
\hline Wu [34] & 2015 & China & Tissue & MSP & $19 / 51$ & $5 / 15$ & $\begin{array}{c}\text { Benign breast } \\
\text { disease }\end{array}$ \\
\hline Asiaf [29] & 2015 & India & Tissue & MSP & $51 / 77$ & $3 / 125$ & $\begin{array}{c}\text { Adjacent matched } \\
\text { normal breast } \\
\text { tissues }\end{array}$ \\
\hline Spitzwieser [12] & 2015 & Austria & Tissue & MS-HRM & $11 / 6$ & $1 / 3$ & $\begin{array}{c}\text { Normal breast } \\
\text { biopsies }\end{array}$ \\
\hline
\end{tabular}

Table 2. Characteristics of studies included in the meta-analysis for the association between MGMT methylation and clinicopathologic features of breast cancer. MS-HRM: methylation-sensitive high-resolution melting; MSP: Methylation-specific PCR; qMSP: Quantitative methylation-specific PCR; BM: bone marrow; BLBC: basal-like breast cancer; DCIS: ductal carcinoma in situ; IDC: Invasive ductal carcinoma

\begin{tabular}{|c|c|c|c|c|c|}
\hline First author & Year & Country & Methods & Materials & Patients characteristics \\
\hline Zemlyakova[32] & 2003 & Russia & Multiplex MS-PCR & Tissue & Sporadic breast cancer \\
\hline Munot MD [4] & 2006 & UK & MSP & Tissue & Invasive breast tumours \\
\hline TABACK [25] & 2006 & USA & q MSP & Serum & $\begin{array}{l}\text { Early stage patients undergoing } \\
\text { surgery for breast cancer }\end{array}$ \\
\hline $\begin{array}{l}\text { Fu [unpublished } \\
\text { data] }\end{array}$ & 2009 & China & $\begin{array}{l}\text { Multiplex nested- } \\
\text { MSP }\end{array}$ & Plasma & $\begin{array}{l}\text { Breast cancer patients (IDC, DCIS } \\
\text { and others) }\end{array}$ \\
\hline Sharma [22] & 2010 & India & MSP & Tissue & $\begin{array}{l}\text { Untreated primary invasive ductal } \\
\text { breast carcinoma patients }\end{array}$ \\
\hline Sharma [22] & 2010 & India & MSP & Serum & $\begin{array}{l}\text { Untreated primary invasive ductal } \\
\text { breast carcinoma patients }\end{array}$ \\
\hline Fumagalli [24] & 2012 & Italy & MSP & Tissue & $\begin{array}{c}\text { Patients with triple-negative breast } \\
\text { cancer }\end{array}$ \\
\hline TSERGA [23] & 2012 & Greece & MS-HRM & Tissue & Patients with invasive breast cancer \\
\hline Lu [33] & 2012 & China & MSP & Tissue & $\begin{array}{l}\text { Invasive ductal breast carcinoma } \\
\text { patients }\end{array}$ \\
\hline Klajic [30] & 2013 & Norway & pyrosequencing & Tissue & $\begin{array}{l}\text { Breast cancer patients with DCIS to } \\
\text { invasive tumours stage I to IV }\end{array}$ \\
\hline Alkam [31] & 2013 & Japan & MSP & Tissue & $\begin{array}{l}\text { Locally advanced Japanese BLBC } \\
\text { patients }\end{array}$ \\
\hline $\mathrm{Fu}[35]$ & 2014 & China & MSP & Tissue & $\begin{array}{l}\text { Breast cancer patients (Non- } \\
\text { invasive and Invasive) }\end{array}$ \\
\hline Spitzwieser [12] & 2015 & Austria & MS-HRM & Tissue & $\begin{array}{l}\text { Breast cancer patients without a } \\
\text { family history of breast cancer }\end{array}$ \\
\hline Asiaf [29] & 2015 & India & MSP & Tissue & $\begin{array}{c}\text { Invasive ductal breast carcinoma } \\
\text { patients of Kashmir }\end{array}$ \\
\hline Wu [34] & 2015 & China & MSP & Tissue & $\begin{array}{c}\text { Female breast cancer patients } \\
\text { (82.9\% for invasive breast cancer) }\end{array}$ \\
\hline
\end{tabular}




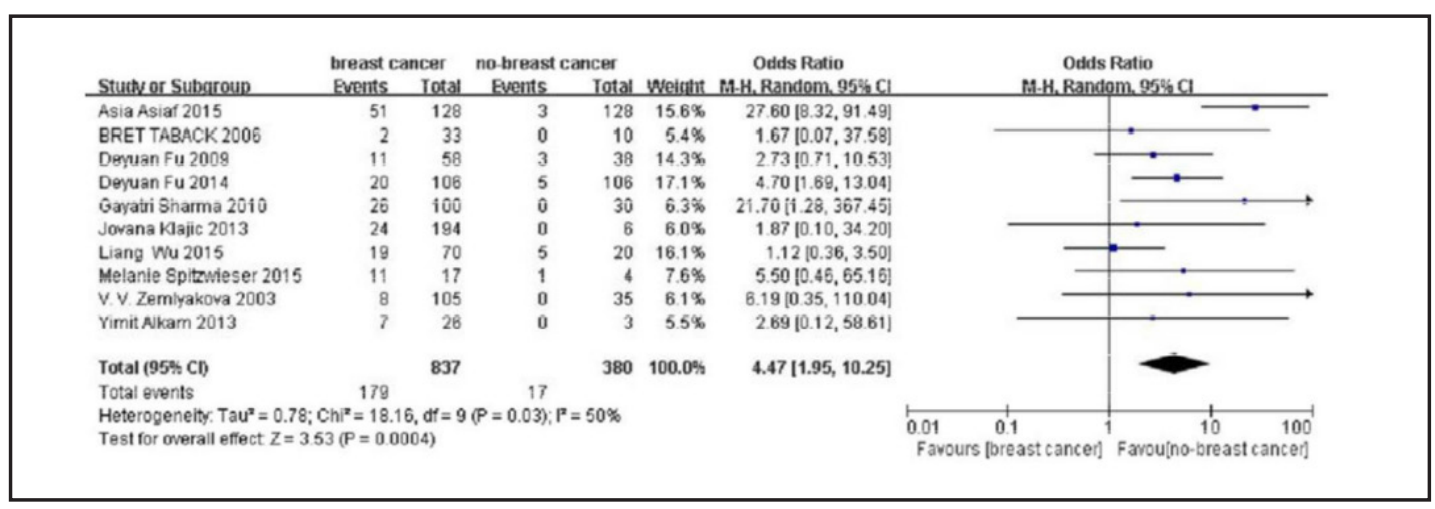

Fig. 2. Forest plot for evaluating the association of MGMT promoter methylation with breast cancer risk. A random-effect model was used for the analysis.

Table 3. Stratification analysis for the association between MGMT promoter methylation and different subgroups of breast cancer

\begin{tabular}{|c|c|c|c|c|c|c|c|c|}
\hline \multirow{2}{*}{\multicolumn{2}{|c|}{ Subgroup category }} & \multirow[t]{2}{*}{ Number of studies } & \multicolumn{3}{|c|}{ Methylation } & \multicolumn{2}{|c|}{$\begin{array}{c}\text { Heterogeneit } \\
y\end{array}$} & \multirow{2}{*}{$\begin{array}{c}\text { Publication bias } \\
\mathrm{P}\end{array}$} \\
\hline & & & OR & $P$ & $95 \% \mathrm{CI}$ & $\mathrm{I}^{2}$ & $P$ & \\
\hline \multirow{2}{*}{ Methods } & MSP & 5 & 5.81 & 0.01 & {$[1.43,23.54]$} & $76 \%$ & 0.002 & 0.818 \\
\hline & Others & 5 & 3.05 & 0.02 & {$[1.15,8.08]$} & $0 \%$ & 0.95 & 0.855 \\
\hline \multirow{3}{*}{ Materials } & Blood & 3 & 3.78 & 0.05 & {$[1.01,14.18]$} & $14 \%$ & 0.31 & 0.722 \\
\hline & Tissue & 7 & 4.57 & 0.006 & {$[1.56,13.43]$} & $62 \%$ & 0.02 & 0.885 \\
\hline & Total & 10 & 4.47 & 0.0004 & {$[1.95,10.25]$} & $50 \%$ & 0.03 & 0.979 \\
\hline
\end{tabular}

837 cases and 380 controls elucidated the association between MGMT methylation and the breast cancer risk. Ten studies from 9 articles [4, 22-24, 29, 31, 33-35] analysed the association of MGMT promoter methylation with the clinicopathological features of breast cancer. The characteristics of these studies, included in the control and case groups, are shown in Table 1 and Table 2, respectively.

\section{The Results of the Meta-analysis}

Association of MGMT promoter methylation with breast cancer risk. Our results showed that the frequency of MGMT promoter methylation in the breast cancer groups was significantly higher than in the non-breast cancer groups $(\mathrm{OR}=4.47,95 \% \mathrm{CI}=1.95-10.25, \mathrm{P}$ $=0.0004)$, as shown in Fig. 2. Because of the existence of heterogeneity $\left(P=0.03, I^{2}=50 \%\right)$ in our results, we performed a subgroup analysis based on the retrieved sample materials and methylation detection methods to find the potential sources of heterogeneity. The subsequent detailed results of the stratification analysis are summarized in Table 3. The consolidated OR using MSP was $5.81(95 \% \mathrm{CI}=1.43-23.54, \mathrm{P}=0.01)$, which was significantly higher than the others $(\mathrm{OR}=3.05,95 \% \mathrm{CI}=1.15-8.08, \mathrm{P}=0.02)$ in the subgroup analysis, classified by methylation assay methods. Furthermore, the consolidated OR of the breast cancer patients compared with healthy women or benign female participants was $4.57(95 \% \mathrm{CI}=1.56-13.43$, $\mathrm{P}=0.006)$ in tissues. The results of the subgroup analysis are shown in Table 3.

Association of MGMT promoter methylation with clinicopathological characteristics of breast cancer

Our results suggested that MGMT promoter methylation was significantly associated with the negative expression of the MGMT protein $(\mathrm{OR}=4.65,95 \% \mathrm{CI}=2.66-8.12$, $\mathrm{P}<0.00001)$, postmenopausal status $(\mathrm{OR}=1.84,95 \% \mathrm{CI}=1.18-2.87, \mathrm{P}=0.007)$, ER-negative tumours (OR $=1.79,95 \% \mathrm{CI}=1.09-2.93, \mathrm{P}=0.02)$ and histological grade III tumours (OR $=2.49,95 \% \mathrm{CI}=1.53-4.07, \mathrm{P}=0.0003$ ) in breast cancer, as shown in Figures 3, 4, 5 and 6 . Similarly, as shown in Table 4, MGMT promoter methylation was not significantly associated 


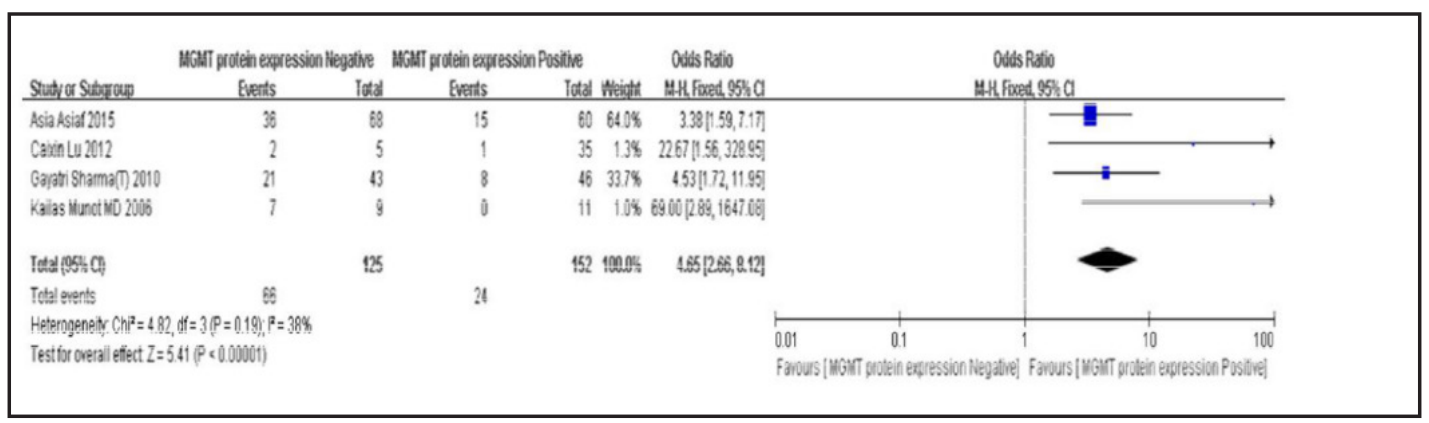

Fig. 3. Fixed effects OR with $95 \%$ CI for evaluating the association between MGMT promoter methylation and MGMT protein expression in breast cancer.

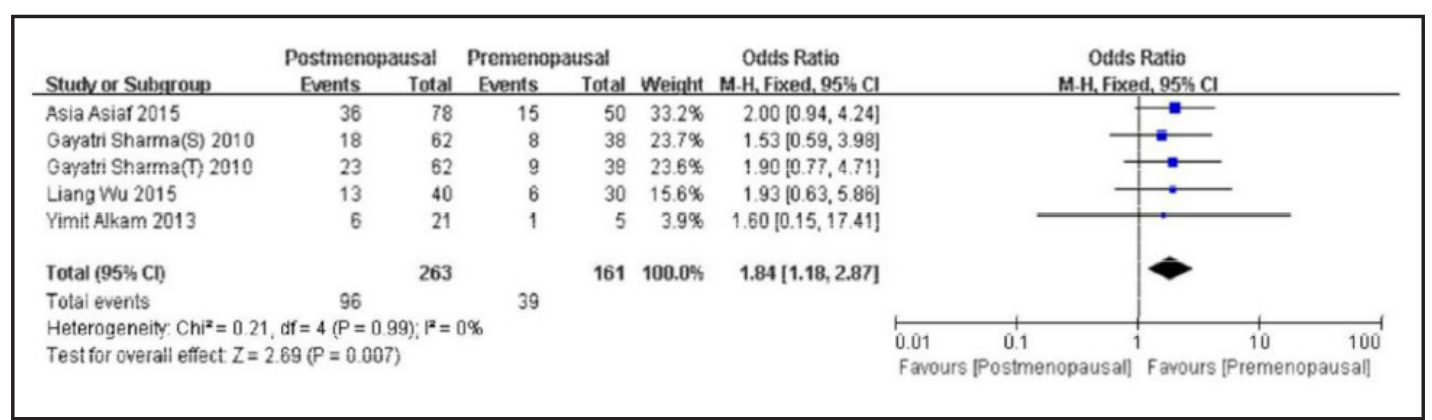

Fig. 4. Forest plot for evaluating the association of MGMT promoter methylation with menopausal status in breast cancer. A fixed-effect model was used for the analysis.

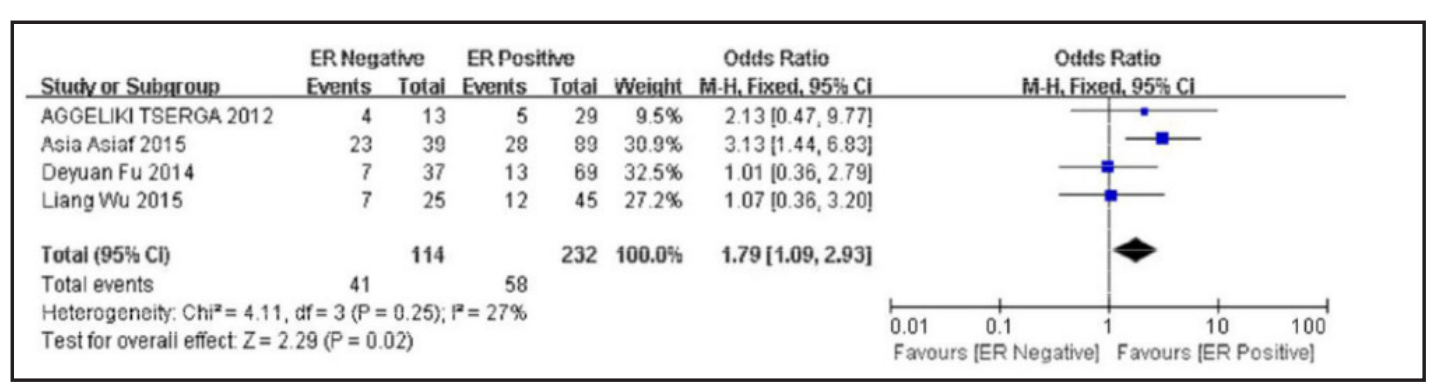

Fig. 5. Fixed effects OR with $95 \% \mathrm{CI}$ for evaluating the association of MGMT promoter methylation with ER status in breast cancer.

with the P53 mutation (OR $=1.30,95 \% \mathrm{CI}=0.76-2.21, \mathrm{P}=0.34)$, PR status $(\mathrm{OR}=1.08$, $95 \% \mathrm{CI}=0.58-2.00, \mathrm{P}=0.81)$, HER-2 $/$ neu status $(\mathrm{OR}=1.01,95 \% \mathrm{CI}=0.65-1.57, \mathrm{P}=0.97)$, lymph node metastasis $(\mathrm{OR}=1.1995 \% \mathrm{CI}=0.83-1.70, \mathrm{P}=0.35)$ and age $>50(\mathrm{OR}=1.07$, $95 \% \mathrm{CI}=0.46-2.51, \mathrm{P}=0.88)$.

\section{Sensitivity analysis and publication bias assessment}

We used Begg's funnel plot and Egger's linear regression test by STATA 13.1 software to evaluate the publication bias of the included studies. The funnel plot (Fig. 7) showed the basic symmetrical distribution of literature and the P value of Egger's linear regression test ( $p=0.783$, Table 3 ) was greater than 0.05 , indicating that there was no publication bias in the study on the association of MGMT promoter methylation with the risk of breast cancer. The P values of Egger's linear regression test for the association between MGMT promoter methylation and clinicopathological features of breast cancer are shown in Table 4. Only the $P$ value for the negative expression of the MGMT protein $(P=0.008)$ was less than 0.05 , suggesting a small publication bias in the study. Moreover, the P values for Egger's linear regression test for subgroup analysis were all greater than 0.05 (Table 3), showing KARGER 


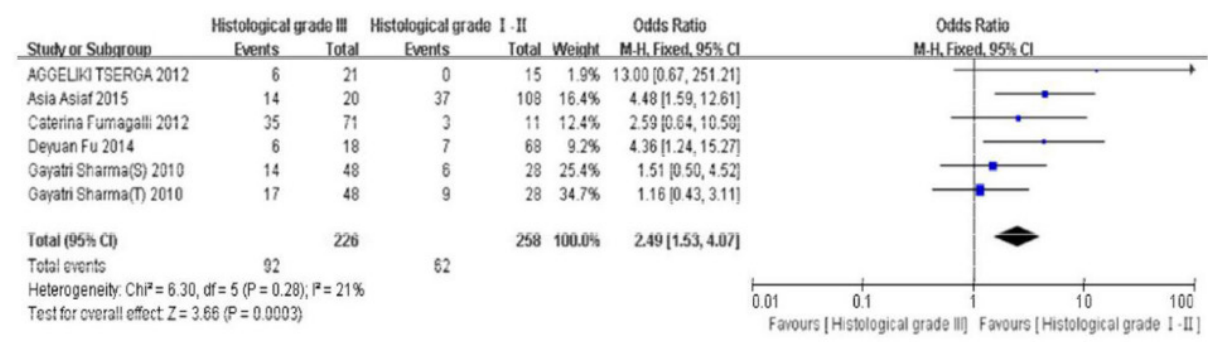

Fig. 6. Fixed effects OR with $95 \% \mathrm{CI}$ for evaluating the association of MGMT promoter methylation with the histological grade tumours in breast cancer.

Table 4. Analysis of the MGMT gene promoter methylation and clinicopathological characteristics of breast cancer

\begin{tabular}{lcccccc}
\hline \multirow{2}{*}{ Clinical and pathological characteristics } & \multicolumn{3}{c}{ Methylation } & \multicolumn{2}{c}{ Heterogeneity } & \multicolumn{2}{c}{ Publication bias } \\
\cline { 2 - 7 } & OR & P & 95\%CI & $\mathrm{I}^{2}$ & $\mathrm{P}$ & $\mathrm{P}$ \\
\hline P53 status & 1.30 & 0.34 & {$[0.76,2.21]$} & $0 \%$ & 0.54 & 0.669 \\
ER Negative & 1.79 & 0.02 & {$[1.09,2.93]$} & $27 \%$ & 0.25 & 0.540 \\
Postmenopausal & 1.84 & 0.007 & {$[1.18,2.87]$} & $0 \%$ & 0.99 & 0.522 \\
HER - / neu Negative & 1.01 & 0.97 & {$[0.65,1.57]$} & $0 \%$ & 0.48 & 0.352 \\
Histological grade III & 2.49 & 0.0003 & {$[1.53,4.07]$} & $21 \%$ & 0.28 & 0.262 \\
MGMT protein negative & 4.65 & $<0.00001$ & {$[2.66,8.12]$} & $38 \%$ & 0.19 & 0.008 \\
Age/year > 50 & 1.07 & 0.88 & {$[0.46,2.51]$} & $77 \%$ & 0.007 & 0.913 \\
PR Negative & 1.08 & 0.81 & {$[0.58,2.00]$} & $59 \%$ & 0.03 & 0.809 \\
Lymph node metastasis & 1.19 & 0.35 & {$[0.83,1.70]$} & $0 \%$ & 0.54 & 0.713 \\
\hline
\end{tabular}

the absence of a publication bias. Sensitivity analysis (Fig. 8) was conducted by ignoring individual studies to examine the change in the integration outcome. Sensitivity analysis in our meta-analysis showed that the results were stable with no significant changes in the omission of individual studies.

\section{Discussion}

Although the specific pathogenesis of breast cancer, a major malignant disease threatening women's health globally in recent years, is not yet clear, it is undeniable that abnormal DNA methylation is an important molecular mechanism in tumour formation. MGMT is located on the chromosome 10q26 and plays a key role in DNA repair. Our comprehensive survey included 10 studies with

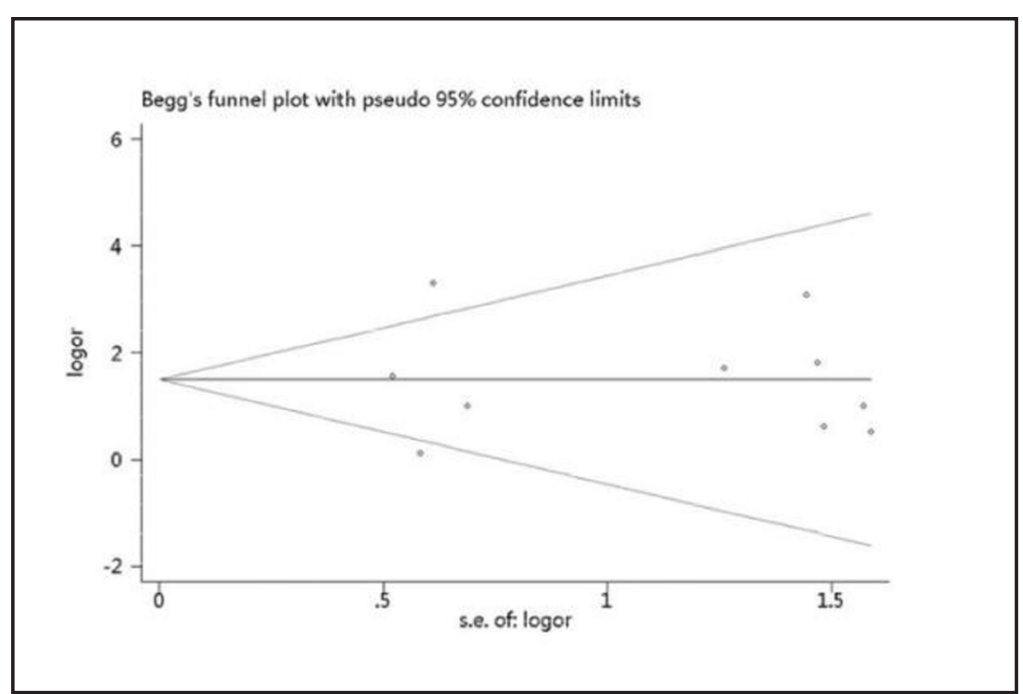

Fig. 7. Begg's funnel plot seeking publication bias for the association of MGMT promoter methylation and breast cancer risk. 
837 cases and 380 controls to explore the association between MGMT promoter methylation and the risk of breast cancer. Our results showed that the methylation of the MGMT promoter in the breast cancer group was 4.47 times higher than that in the non-breast cancer group, which further illustrated a statistically significant association. Moreover, our study verified that MGMT methylation was significantly related to the negative expression of the MGMT protein, ER-negative tumours, postmenopau-

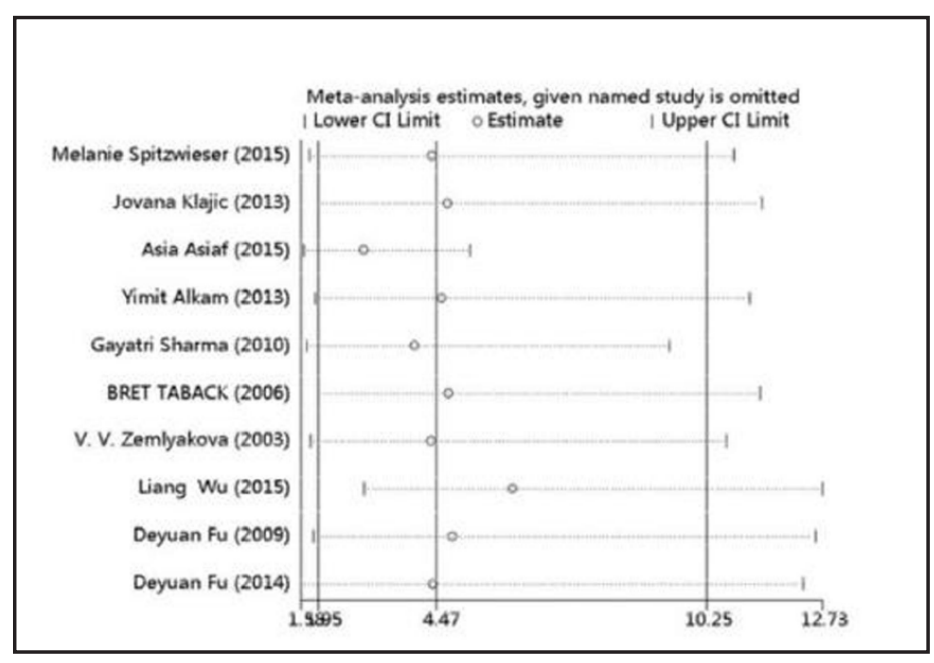

Fig. 8. Diagram for sensitivity analysis for evaluating the association of MGMT promoter methylation with breast cancer risk. sal status and histological grade III tumours in breast cancer. Our research suggested that the methylation of the MGMT promoter may be a potential biomarker for the diagnosis of breast cancer. The abundance of genes in cancer tissues, abnormalities in the early stages of cancer formation, the relative stability of methylated biomarkers and the easily detectable changes in serum, sputum, or minimally invasive surgery facilitate the use of monitoring sequences containing DNA promoter hypermethylation of $\mathrm{CpG}$ islands as a diagnostic tool in cancer [36]. The methylation of the MGMT promoter could be a powerful, potential biomarker in the clinical diagnosis and prognosis of breast cancer.

Our study demonstrated a significantly strong association between the frequency of MGMT gene promoter methylation and the risk of breast cancer, indicating that the abnormal methylation of the MGMT promoter would elevate the risk of breast cancer. In the subgroup analysis grouped with sample materials, our data showed that the combined $\mathrm{OR}$ in tissues $(\mathrm{OR}=4.57)$ was higher than in blood samples $(\mathrm{OR}=3.78)$, indicating a higher risk of breast cancer in tissues. Notably, DNA can be easily extracted from serum or plasma with small trauma. It is more interesting to extract DNA from bone marrow aspirates [25]. Thus, these studies are innovative in the diagnosis of breast cancer. Furthermore, there were 5 studies in the MSP groups $(\mathrm{OR}=5.81)$ and 5 studies in Others $(\mathrm{OR}=3.05)$ in the subgroup analysis based on MGMT methylation detection methods. Accordingly, different methods of MGMT methylation detection may affect the early diagnosis of breast cancer, and it is important to select the appropriate methods that can be used to guide clinical practices.

In recent decades, the studies on the inverse relationship between the MGMT promoter methylation and MGMT protein negative expression have been increasing in epigenetics. Our findings were consistent with the results of Asiaf ( $r s=-0.285, p<0.05$ ) [29] and Sharma $(\mathrm{p}=0.002, \mathrm{OR}=4.5,95 \% \mathrm{CI}=1.7-12.0)[22]$ that the MGMT promoter methylation was significantly associated with the negative expression of the MGMT protein. Thus, MGMT promoter methylation was not associated with breast cancer patients who were over 50 years of age in our study. However, Tserga et al. believed that MGMT methylation was more often observed in older patients (Mann-Whitney U test, $p=0.0222$ ) [23]. When we extracted the age data related to the MGMT promoter methylation, we classified the breast cancer patients $>50$ years of age into the experimental group and $\leq 50$ years old into the control group. Unexpectedly, patients $\geq 50$ years old were divided into the same groups as in the two studies by Fu [35] and Fumagalli [24]. We speculated that the threshold of age caused this difference; thus, further studies are needed to demonstrate the association between MGMT methylation and age. 
Our results showed that MGMT promoter methylation had an enhanced association with the ER-negative tumours, indicating that such breast tumours rarely benefit from traditional hormone therapy. However, MGMT methylation was not associated with the PR status or the Her2 and P53 status. Similarly, our comprehensive survey showed that the MGMT promoter methylation was not significantly associated with the lymph node metastasis in breast cancer. Interestingly, we found that the MGMT promoter methylation was significantly associated with the postmenopausal status, suggesting an increase in the risk of breast cancer in older women. Moreover, our meta-analysis showed that the association between the MGMT promoter methylation and the histological grade III tumours was more significant in the breast cancer group compared with the control group.

Although our study used a rational design and good procedure implementation, there were some limitations. First, this meta-analysis was a comprehensive investigation on the basis of case-control studies, which may have a selection bias of literature. Second, our results did not consistently show an association between the frequency of MGMT promoter methylation and the risk of breast cancer. We used subgroup analysis and regression analysis to determine the sources of heterogeneity in our results. Our results showed that sample materials and methylation detection methods were not significant factors in causing heterogeneity. However, from a professional perspective, the differences in methods and materials may cause heterogeneity among studies, pending further studies based on the exploration of large samples. We also did a sensitivity analysis by eliminating the studies one by one but did not identify the factors that could significantly affect heterogeneity. Third, to a certain extent, the absence of a clear definition of a control group affected the results of our study. Furthermore, since this study was an analysis based on the original data from relevant studies, it was not possible to correct the confounding factors in the original data such as age, race, and sex. Finally, the lack of original data from the existing research limited our further assessment of the potential association between MGMT methylation and breast cancer.

\section{Conclusion}

Our study suggested that the methylation of the MGMT promoter was significantly associated with the risk of breast cancer and several clinicopathological features. Compared with patients with breast cancer, the prevalence of MGMT methylation in healthy women or benign female patients was significantly lower. The prevalence of MGMT methylation was closely associated with the negative expression of the MGMT protein, ER-negative tumours, postmenopausal status and histological grade III tumours in breast cancer patients. The detection of MGMT methylation might provide a highly specific and sensitive molecular substitute for diagnosis and clinical management of breast cancer. However, studies based on large samples and well-defined control groups are necessary before MGMT is deemed a biomarker for the diagnosis and prognosis of breast cancer.

\section{Acknowledgements}

This work was supported by grants from National Natural Science Foundation of China (81272372 and 30873044). The Project-sponsored by SRF for ROCS, SEM.

\section{Disclosure Statement}

The authors declare that there is no conflict of interests regarding the publication of this paper. 


\section{Cellular Physiology Cell Physiol Biochem 2017;42:2430-2440 \begin{tabular}{ll|l} 
and Biochemistry Published online: August 21, 2017 & $\begin{array}{l}\text { (C) } 2017 \text { The Author(s). Published by S. Karger AG, Basel } \\
\text { www.karger.com/cpb }\end{array}$ \\
\hline
\end{tabular}}

An et al.: MGMT Promoter Methylation in Breast Cancer

\section{References}

1 Chin L, Andersen JN, Futreal PA: Cancer genomics: from discovery science to personalized medicine. Nat Med 2011;17:297-303.

-2 Deo S, Bhutani M, Shukla NK, Raina V, Rath GK, Purkayasth J: Randomized trial comparing neo - adjuvant versus adjuvant chemotherapy in operable locally advanced breast cancer (T4b N0 - 2 M0). J Surg Oncol 2003;84:192-197.

3 Jemal A, Murray T, Ward E, Samuels A, Tiwari RC, Ghafoor A, Feuer EJ, Thun MJ: Cancer statistics, 2005. CA Cancer J Clin 2005;55:10-30.

4 Munot K, Bell SM, Lane S, Horgan K, Hanby AM, Speirs V: Pattern of expression of genes linked to epigenetic silencing in human breast cancer. Hum Pathol 2006;37:989-999.

5 Parkin DM, Bray F, Devesa S: Cancer burden in the year 2000. The global picture. Eur J Cancer 2001;37:466.

Parkin DM, Bray F, Ferlay J, Pisani P: Global cancer statistics, 2002. CA Cancer J Clin 2005;55:74-108.

Esteller M, Corn PG, Baylin SB, Herman JG: A gene hypermethylation profile of human cancer. Cancer Res 2001;61:3225-3229.

8 Toh Y, Egashira A, Yamamoto M: Epigenetic alterations and their clinical implications in esophageal squamous cell carcinoma. Gen Thorac Cardiovasc Surg 2013;61:262-269.

9 Gao Y, Feng B, Han S, Lu L, Chen Y, Chu X, Wang R, Chen L: MicroRNA-129 in Human Cancers: from Tumorigenesis to Clinical Treatment. Cell Physiol Biochem 2016;39:2186-2202.

10 Jones PA, Baylin SB: The epigenomics of cancer. Cell 2007;128:683-692.

11 Simó-Riudalbas L, Esteller M: Cancer genomics identifies disrupted epigenetic genes. Hum Genet 2014;133:713-725.

12 Spitzwieser M, Holzweber E, Pfeiler G, Hacker S, Cichna-Markl M: Applicability of HIN-1, MGMT and RASSF1A promoter methylation as biomarkers for detecting field cancerization in breast cancer. Breast Cancer Res 2015;17:125.

13 Bird A: DNA methylation patterns and epigenetic memory. Genes Dev 2002;16:6-21. Issa JP, Kantarjian HM: Targeting DNA methylation. Clin Cancer Res 2009;15:3938-3946.

15 Sun J-J, Chen G-Y, Xie Z-T: MicroRNA-361-5p inhibits cancer cell growth by targeting CXCR6 in hepatocellular carcinoma. Cell Physiol Biochem 2016;38:777-785.

16 Teng Y, Zuo X, Hou M, Zhang Y, Li C, Luo W, Li X: A Double-Negative Feedback Interaction between MicroRNA-29b and DNMT3A/3B Contributes to Ovarian Cancer Progression. Cell Physiol Biochem 2016;39:2341-2352.

17 Gerson SL: MGMT: its role in cancer aetiology and cancer therapeutics. Nat Rev Cancer 2004;4:296-307.

18 Olsson M, Lindahl T: Repair of alkylated DNA in Escherichia coli. Methyl group transfer from 06methylguanine to a protein cysteine residue. J Biol Chem 1980;255:10569-10571.

19 Daniels DS, Woo TT, Luu KX, Noll DM, Clarke ND, Pegg AE, Tainer JA: DNA binding and nucleotide flipping by the human DNA repair protein AGT. Nat Struct Mol Biol 2004;11:714-720.

20 Pegg AE: Repair of 0 6-alkylguanine by alkyltransferases. Mutat Res Rev Mutat Res 2000;462:83-100.

21 Srivenugopal KS, Yuan X-H, Friedman HS, Ali-Osman F: Ubiquitination-dependent proteolysis of O 6-methylguanine-DNA methyltransferase in human and murine tumor cells following inactivation with 0 6-benzylguanine or 1, 3-bis (2-chloroethyl)-1-nitrosourea. Biochemistry 1996;35:1328-1334.

22 Sharma G, Mirza S, Parshad R, Srivastava A, Gupta SD, Pandya P, Ralhan R: Clinical significance of promoter hypermethylation of DNA repair genes in tumor and serum DNA in invasive ductal breast carcinoma patients. Life Sci 2010;87:83-91.

23 Tserga A, Michalopoulos NV, Levidou G, Korkolopoulou P, Zografos G, Patsouris E, Saetta AA: Association of aberrant DNA methylation with clinicopathological features in breast cancer. Oncol Rep 2012;27:1630.

-24 Fumagalli C, Pruneri G, Possanzini P, Manzotti M, Barile M, Feroce I, Colleoni M, Bonanni B, Maisonneuve P, Radice P: Methylation of 06-methylguanine-DNA methyltransferase (MGMT) promoter gene in triplenegative breast cancer patients. Breast Cancer Res Treat 2012;134:131-137.

25 Taback B, Giuliano AE, Lai R, Hansen N, Singer FR, Pantel K, Hoon DS: Epigenetic Analysis of Body Fluids and Tumor Tissues. Ann N Y Acad Sci 2006;1075:211-221.

-26 Higgins J, Thompson SG: Quantifying heterogeneity in a meta - analysis. Stat Med 2002;21:1539-1558.

27 DerSimonian R, Laird N: Meta-analysis in clinical trials. Control Clin Trials 1986;7:177-188. 


\section{Cellular Physiology Cell Physiol Biochem 2017;42:2430-2440

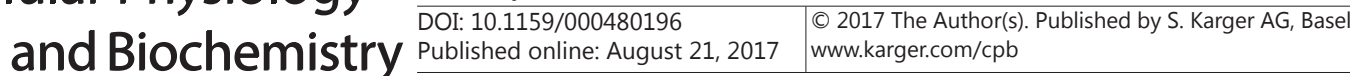

An et al.: MGMT Promoter Methylation in Breast Cancer

28 Higgins J, Thompson SG, Deeks JJ, Altman DG: Measuring inconsistency in meta-analyses [journal article as teaching resource, deposited by John Flynn]. BMJ 2003;327:557-560.

-29 Asiaf A, Ahmad ST, Malik AA, Aziz SA, Rasool Z, Masood A, Zargar MA: Protein expression and methylation of MGMT, a DNA repair gene and their correlation with clinicopathological parameters in invasive ductal carcinoma of the breast. Tumor Biol 2015;36:6485-6496.

-30 Klajic J, Fleischer T, Dejeux E, Edvardsen H, Warnberg F, Bukholm I, Lønning PE, Solvang H, BørresenDale A-L, Tost J: Quantitative DNA methylation analyses reveal stage dependent DNA methylation and association to clinico-pathological factors in breast tumors. BMC Cancer 2013;13:456.

-31 Alkam Y, Mitomi H, Nakai K, Himuro T, Saito T, Takahashi M, Arakawa A, Yao T, Saito M: Protein expression and methylation of DNA repair genes hMLH1, hMSH2, MGMT and BRCA1 and their correlation with clinicopathological parameters and prognosis in basal - like breast cancer. Histopathology 2013;63:713725.

-32 Zemlyakova V, Zhevlova A, Strelnikov V, Lyubchenko L, Schabanov M, Vishnevskaya YV, Tretyakova V, Zaletayev D, Nemtsova M: Abnormal methylation of several tumor suppressor genes in sporadic breast cancer. Mol Biol 2003;37:591-597.

33 Lu C, Wu Y: Expression of MGMT Gene in Breast Cancer and Its Significance. Mod Diagn Treat 2012;23:886887.

34 Wu L, Wang J: Study on the Correlation between Abnormal DNA Methylation and Clinical Features of Breast Cancer. J Med Res 2016;45:82-86.

35 Fu D, Wei J, Zhu Y, Tan H, Zhang J: Clinical significance of BRCA1, GSTP1 and MGMT gene methylation status in breast cancer. China Oncol 2014;24:487-492.

-36 Laird PW: The power and the promise of DNA methylation markers. Nat Rev Cancer 2003;3:253-266. 